\title{
Skitterende boek oor spanning, uitbranding en vrees
}

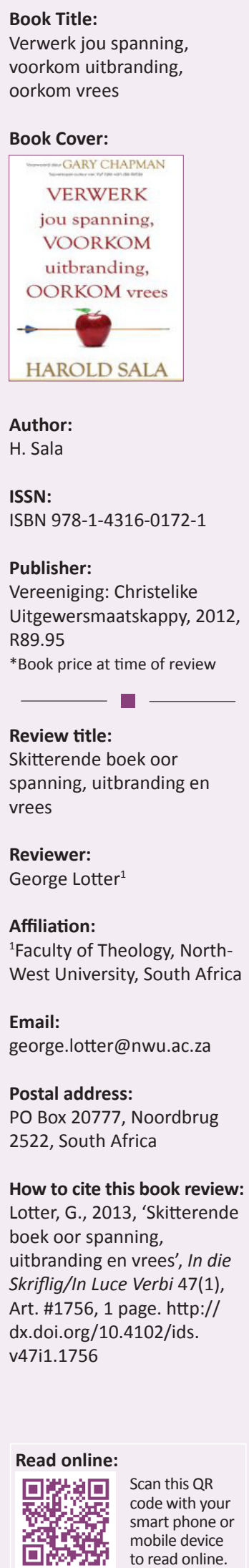

Die Christelike Uitgewersmaatskappy (CUM) het die land 'n guns bewys om hierdie boek wat reeds in 1996 en 2009 verskyn het, te laat vertaal en in Afrikaans bekend te stel. Lesers in Afrikaans het juis nou nodig om so'n redelik omvattende werk oor die sake wat in die titel genoem word, te lees. Dit is noodsaaklik om sulke materiaal te publiseer vanweë die aktualiteit van byvoorbeeld stres en uitbranding in die Suid-Afrikaanse samelewing. Boonop is die werk sterk Skrifgefundeerd en nie soos 'n mens soms by vertaalde werke ervaar, maar eintlik sielkundige verduidelikings met 'n Christelike 'sousie' oor nie.

Die boek het ' $n$ besonder logiese aanpak: Dit begin by wat genoem word 'God se plan vir jou emosies'. Dit beweeg dan aan na begrip vir jouself en wie jy is in terme van wat Paulus in Romeine 8:1 geskryf het: 'Daar is dus nou geen veroordeling vir dié wat in Christus Jesus is nie' (bl. 20). Vanuit 'n reformatoriese hoek is hierdie vertrekpunt te verwelkom omdat daar dikwels 'n meer humanistiese benadering gevolg word met die boodskap: Jy in jouself goed en aanvaarbaar.

Daarna word 'n hele paar hoofstukke gewy aan die menslike emosie. Dit is ook te verwelkom, veral in die lig van die eensydige benadering vroeër in die modernistiese era wat tot die 'onderdrukking van emosie' en 'n fokus op die rasionele gelei het en die ander uiterste naamlik die 'uiting gee aan alle emosie' in die postmoderne tyd waarin ons leef. Op bladsy 52 gee die skrywer byvoorbeeld definisies van wat emosie is. Dis duidelik dat die skrywer, Harold Sala, baie ervaring en kundigheid het oor die mens se 'wonder oor wie jy regtig is en jou stand in die lewe'. Tog is sy benadering suiwer soos dit op bladsy 45 genoem word: Aanvaarding in ' $n$ Bybelse perspektief.

Op 'n tipies Amerikaanse manier beskryf hy dikwels puntsgewys die voor- en nadele van sekere sake asook die hoe-om-dinge-te doen (how-to) soos byvoorbeeld in bladsy 115 en verder met die opskrif: Leer om woede te hanteer (hoofstuk 6 handel volledig oor woede).

Die res van boek (hoofstuk 7-11) handel oor kommer, vrees, verveling, stres en uitbranding. Die titel van die boek weerspieël nie eintlik die mate van aandag wat aan die verskillende subtemas gegee word nie, maar die titel trek tog aandag en sal veroorsaak dat mense dit wil koop.

Wat ek veral van die boek gehou het, is die balans tussen die beskrywing van ware gebeurtenisse, die stel van die 'teorie', Skriftuurlike fundering en praktiese riglyne vir die leser hoe om sekere sake te hanteer.

Dit is dus met groot vrymoedigheid dat ek die boek vir 'n verskeidenheid lesers aanbeveel: 'gewone' mense en lidmate van die kerk wat self met dié sake sukkel; predikante, pastore en beraders wat self heelwat uit die boek kan leer en dan mense wat persone naby hulle het wat met spanning, vrees, uitbranding en bekommernis worstel. Die boek lees maklik en is uit 'n redigeringsoogpunt goed geskryf om mens se aandag te behou.

Sterk aanbeveel! 